\title{
TIME LOAD UPON STUDENTS IN PRIMARY EDUCATION
}

Dr. Borce Kostov, Faculty of Philosophy, University St. Cyril and Methodius, Skopje, Republic od Macedonia E-mail: borce.kostov@fzf.ukim.edu.mk

M.A. Ankica Antovska, State University of Tetovo, Republic od Macedonia

E-mail: ane_prima@yahoo.com

A R T I C L E I N F O

Original Article

Received: November, 15.2016.

Revised: December, 08.2016.

Accepted: December, 12.2016.

doi:10.5937/IJCRSEE1602047K

UDK

373.3.214.6(497.7)"2016"

159.944.4-057.874(497.7)"2016"

\section{Keywords:}

time load,

overload,

optimal load,

primary school,

primary education.
A B S T R A C T

Time load upon students is a central issue in the context of the overall load placed upon students. Most authors dealing with the issue of load upon students mainly approach this issue from the aspect of the time the students need to respond to the requirements posed by the school and otherwise concerning school. Such load is called time load. In our research, we investigated exactly this kind of time load placed upon students in the nine-year primary education in Macedonia. The main goal of our research was getting insight what is the students' time load like and how big it is.

(C) 2016 IJCRSEE. All rights reserved.

\section{INTRODUCTION}

Searching through the literature whose object is time load upon students in modern schools, we got to the insight that this problem is mainly researched from the aspect of changes in the curriculums. (Bezinović, Ristić-Dedić, 2004).

This way, in example, Blank, Melaville and Shah, 2003 oriented their research towards the possibilities for reforming the curriculum and syllabus in schools. They paid special attention to the issues of schoolmasters and teachers' values, attitudes and activities regarding the scope and the quality of the curriculum, or, how solving these issues will influence the problem of time load upon students. (Blank, Melaville and Shah, 2003)

According to the research performed by Hara and Burke, 1998, conducted using doorto-door interviews, in 2002 in 8 countries of South-East Europe: Albania, Bosnia and Hercegovina, Kosovo, Macedonia, Montenegro, Serbia, Moldova and Romania, it was estab-

\section{Corresponding Author}

Dr. Borce Kostov, Faculty of Philosophy, University

St. Cyril and Methodius, Republic od Macedonia

E-mail: borce.kostov@fzf.ukim.edu.mk

\section{cc) (†) $\ominus$}

This work is licensed under a Creative Commons Attribution - NonCommercial - NoDerivs 4.0. The article is published with Open Access at www.ijcrsee.com lished that the communication i.e. the cooperation between the school representatives, on one hand, and the parents, on the other, was at a relatively low level. All this had contributed the schools, the local communities and the parents to lack information about students' time load (Hara and Burke, 1998).

In their research, Hara and Burke, 1998 point out that through the years a large number of data and proofs have accumulated about the positive correlation from the involvement of the local community and the parents in the process of education. Such cooperation between the local community, parents and educational institutions very often brings to the surface the problem of students' load, above all from the aspect of the changes in syllabuses (Hara and Burke, 1998).

Petar Bezinović and Zrinka Ristić-Dedić conducted a research trying, among else, to establish how big is students' load with school duties in their daily agenda. Beside having very loaded timetable, the students, according to the results from their research, must also much more prepare for following the lectures and doing homework (Bezinović, RistićDedić, 2004).

\section{MATERIALS AND METHODS}

In our paper, we focused on the issue of time load, since we consider that the load in 
its whole exceeds the scope of an individual investigation, moreover, of an investigation which approaches this issue only from one aspect. This study was conducted in the period from September 2014. until June 2015. among 945 participations, 405 students in primary education, 405 parents of this students and 135 teachers in primary education in Macedonia.

The norms obtained about time load upon students in our sample were compared with the theoretically given norms for optimal load upon students of each particular age. Using the rational comparison with the norms proposed by Lairda we established the factual situation concerning the time load placed upon students in our schools.

The results, the analysis of which follows, show how big the time load is upon students in primary education in the Republic of Macedonia, namely of those from sixth, seventh, eighth and ninth grade.

\section{RESULTS \\ 3.1. Time load upon students in sixth grade}

According to the values given in Table 1 , the arithmetic mean values and standard deviations, we can see that the dispersion of the results regarding students' time load in sixth grade ranges within the limits of 21 to 44 hours and 30 minutes.

These data clearly indicate the factual situation that a certain number of students in sixth grade, so as to satisfy the demands posed by the school, in their work spend double amount of time, and even more, than some other students in the same class.

Table 1. Time load upon students in the representative week for sixth grade; Distribution of frequencies by days, given in minutes and hours

\begin{tabular}{ccccc}
\hline \multicolumn{5}{c}{ Time load } \\
\hline Day & Minutes & Hours & fo & ft \\
\hline 1 & $799-1106$ & - & 0 & 0.61 \\
\hline 2 & $1107-1414$ & $\begin{array}{c}18: 27- \\
23: 33\end{array}$ & 3 & 7.56 \\
\hline 3 & $1415-1722$ & $\begin{array}{c}23: 33- \\
28: 42\end{array}$ & 43 & 33.88 \\
\hline 4 & $1723-2030$ & $\begin{array}{c}28: 42- \\
33: 49\end{array}$ & 56 & 55.83 \\
\hline 5 & $2031-2338$ & $\begin{array}{c}33: 49- \\
38: 58\end{array}$ & 26 & 33.88 \\
\hline 6 & $2339-2646$ & $\begin{array}{c}38: 58- \\
44: 06\end{array}$ & 12 & 7.56 \\
\hline 7 & $2647-2954$ & - & 0 & 0.61 \\
\hline
\end{tabular}

$$
\begin{array}{ll}
X=1877.6 & \sigma=308 \\
i=\sigma=308 & \chi 2=11.64
\end{array}
$$

The time load of 140 students from sixth grade, in 56 cases lies within the limits of 0.5 standard deviation (which is three times higher value than the one corresponding to the normal dispersion), i.e. it is in the range from 1723 minutes to 2030 minutes.

Table 2. Results ( $\mathrm{X}$ and $\sigma$ ) by the success

\begin{tabular}{ccccc}
\hline \multicolumn{5}{c}{ Success } \\
\hline Results & $\mathbf{5}$ & $\mathbf{4}$ & $\mathbf{3}$ & $\mathbf{2}$ \\
\hline $\mathrm{X}$ & 2108 & 2007 & 1782 & 1580 \\
\hline$\sigma$ & 256 & 257 & 225 & 140 \\
\hline
\end{tabular}

The calculated $\chi$-square test shows that the distribution obtained is within the limits of the normal, i.e. it does not significantly deviate from the theoretic distribution which would correspond to our sample from the sixth grade classes of primary school.

If according to Lairda's theoretic norms, quoted in the Encyclopedic Dictionary of Pedagogy, the daily load upon students in sixth grade is 300 minutes, than we can make the claim that all the categories of students in sixth grade are burdened above the theoretic norms for the time load upon children at this age, or that the students in sixth grade are overloaded in the educational process.

\subsection{Time load upon students in seventh grade}

Regarding the data obtained by investigating students' time load from seventh grade classes, a significant overlap is characteristic between the results obtained in the investigation and the frequencies corresponding to the normal distribution, which preconditions concentration of the results around the arithmetic mean value within the limits of normal distribution.

The calculated $\chi$-square test (2.43) indicates the representativeness of the sample on which the investigation was performed. The average weekly load of 1921 minutes is a mean value around which are concentrated all the other results with the dispersion of 310 which corresponds to the normal distribution. The average daily time load upon students of seventh grade is 387 minutes. The standard deviation and the tabular presentation of frequencies' dispersion (Tables 3 and 4) show that the students' time load in seventh grade 
ranges within the limits of 2541 and 1301 minutes.

Table 3. Time load upon students in the representative week for seventh grade; Distribution of frequencies by days, given in minutes and hours

\begin{tabular}{ccccc}
\hline \multicolumn{5}{c}{ Time load } \\
\hline Day & Minutes & Hours & f0 & ft \\
\hline 1 & $836-1145$ & - & 0 & 0.61 \\
\hline 2 & $1146-1455$ & $\begin{array}{c}19: 06- \\
24: 15\end{array}$ & 9 & 7.56 \\
\hline 3 & $1456-1765$ & $\begin{array}{c}24: 15- \\
29: 25\end{array}$ & 34 & 33.88 \\
\hline 4 & $1766-2075$ & $\begin{array}{c}29: 25- \\
35: 00\end{array}$ & 55 & 55.83 \\
\hline 5 & $2076-2385$ & $\begin{array}{c}34: 36- \\
39: 45\end{array}$ & 36 & 33.88 \\
\hline 6 & $2386-2695$ & $\begin{array}{c}39: 45- \\
44: 55\end{array}$ & 6 & 7.56 \\
\hline 7 & $2696-3005$ & - & 0 & 0.61 \\
\hline $\mathrm{X}=1921$ & $\sigma=310$ & & & \\
$\mathrm{i}=\sigma=310$ & $\chi^{2}=2.43$ & & &
\end{tabular}

Table 4. Results (X and $\sigma$ ) by the success

\begin{tabular}{cccc}
\hline \multicolumn{3}{c}{ Success } \\
\hline Results & $\mathbf{5}$ & $\mathbf{4}$ & $\mathbf{3}$ \\
\hline $\mathrm{X}$ & 2108 & 2007 & 1782 \\
\hline$\sigma$ & 256 & 257 & 225 \\
\hline
\end{tabular}

Regarding the students from seventh grade classes we obtained average daily time load of 387 minutes, which is above the prescribed limit of 330 minutes. If we compare the theoretic optimal time of 330 minutes with the average time load by the success, we can make the conclusion that only the students achieving satisfactory success, i.e. with pass marks, are slightly less burdened (323 minutes) than the allowed by the theoretic time load norms.

\subsection{Time load upon students in eighth grade}

From the results obtained about the time load of the students from eighth grade classes, we can see that the frequency distribution of students' load is drawn according to the lower results (Tables 5 and 6). However, these deviations are not sufficient for obtaining some significant difference regarding normal distribution of frequency.

Table 5. Time load upon students in the representative week for eighth grade; Distribution of frequencies by days, given in minutes and hours

\begin{tabular}{ccccc}
\hline \multicolumn{5}{c}{ Time load } \\
\hline Day & Minutes & Hours & f0 & ft \\
\hline 1 & $1011-1292$ & - & 0 & 0.61 \\
\hline 2 & $1293-1574$ & $\begin{array}{c}21: 33- \\
26: 14\end{array}$ & 6 & 7.56 \\
\hline 3 & $1575-1856$ & $\begin{array}{c}26: 14- \\
30: 56\end{array}$ & 44 & 33.88 \\
\hline 4 & $1857-2138$ & $\begin{array}{c}30: 56- \\
35: 38\end{array}$ & 41 & 55.83 \\
\hline 5 & $2139-2420$ & $\begin{array}{c}35: 38- \\
40: 20\end{array}$ & 39 & 33.88 \\
\hline 6 & $2421-2702$ & $\begin{array}{c}40: 20- \\
45: 02\end{array}$ & 10 & 7.56 \\
\hline 7 & $2703-2984$ & - & 0 & 1 \\
\hline $\mathrm{X}=1998.1$ & $\begin{array}{c}\sigma=281.75 \\
\mathrm{i}=\sigma=281.75\end{array} \chi^{2}=9.88$ \\
7
\end{tabular}

The average daily time load of 387 minutes is above the theoretically prescribed limit of 360 minutes. Viewed by the success, only those students who achieve satisfactory success, i.e. with pass marks, are burdened slightly less (346 minutes) than the optimal limit, while the time load of all the other categories of students is below the prescribed theoretic norm.

Table 6. Results ( $\mathrm{X}$ and $\sigma$ ) by the success

\begin{tabular}{ccccc}
\multicolumn{5}{c}{ Success } \\
\hline Results & $\mathbf{5}$ & $\mathbf{4}$ & $\mathbf{3}$ & $\mathbf{2}$ \\
\hline $\mathrm{X}$ & 2280 & 2136 & 1842 & 1728 \\
\hline$\sigma$ & 194 & 166 & 193 & 169 \\
\hline
\end{tabular}

\subsection{Time load upon students in ninth grade}

Regarding the results on students' time load from ninth grade classes, most evident is the fact that these students in their work spend the biggest amount of time in the effort to respond to the tasks posed by the school.

The dispersion value obtained is the biggest compared to those obtained for the other grades (sixth, seventh and eighth), thus indicating big differences in the load between 
individual students in ninth grade (Tables 7 and 8).

A very important characteristic of the load in ninth grade classes is the big difference in the load between individual students from the same category (for example, between the students achieving excellent success or between those achieving satisfactory success).

Table 7. Time load upon students in the representative week for ninth grade; Distribution of frequencies by days, given in minutes and hours

\begin{tabular}{ccccc}
\hline \multicolumn{5}{c}{ Time load } \\
\hline Day & Minutes & Hours & f0 & ft \\
\hline 1 & $974-1085$ & - & 0 & 0.61 \\
\hline 2 & $1086-1459$ & $\begin{array}{c}18: 06- \\
24: 14\end{array}$ & 3 & 7.56 \\
\hline 3 & $1460-1833$ & $\begin{array}{c}24: 14- \\
30: 13\end{array}$ & 44 & 33.88 \\
\hline 4 & $1834-2207$ & $\begin{array}{c}30: 33- \\
36: 47\end{array}$ & 55 & 55.83 \\
\hline 5 & $2208-2581$ & $\begin{array}{c}36: 47- \\
43: 00\end{array}$ & 28 & 33.88 \\
\hline 6 & $2582-2955$ & $\begin{array}{c}43: 00- \\
49: 15\end{array}$ & 10 & 7.56 \\
\hline 7 & $2956-3325$ & - & 0 & 1 \\
\hline $\mathrm{X}=2021.3$ & $\begin{array}{c}\sigma=373.76 \\
\chi^{2}=9.55\end{array}$
\end{tabular}

Table 8. Results (X and $\sigma$ ) by the success

\begin{tabular}{ccccc}
\hline \multicolumn{5}{c}{ Success } \\
\hline Results & $\mathbf{5}$ & $\mathbf{4}$ & $\mathbf{3}$ & $\mathbf{2}$ \\
\hline $\mathrm{X}$ & 2315 & 2136 & 1842 & 1710 \\
\hline$\sigma$ & 400 & 166 & 193 & 277 \\
\hline
\end{tabular}

This phenomenon can be explained with the efforts of ninth grade students for achieving as better as possible success because of the requirements imposed by the high schools for enrollment. Therefore, during the final stages of primary education, a number of students invest maximum efforts for achieving as better as possible success which way their burden increases considerably if in the process the students don't possess the other components necessary for successful studying (developed intellectual abilities, good foreknowledge, good learning skills, etc.).

The calculated $\chi$-square test (9.55) shows that the distribution between the ob- tained and the expected frequencies considerably differs.

\section{ANALYSIS OF RESULTS AND DISCUSSION}

The analysis of time load upon students by particular grades has shown that, in general, the obtained distribution of frequencies according to the statistic criterions is within the normal curve. Such results indicate the representativeness of the arithmetic mean values by grades, the methodological justification of the selection of a representative week for calculating the parameters needed, and especially the possibility for using these results as norms for valuating students' load in particular grades.

That's why we compared the obtained data on time load of the students covered in our sample with the theoretically given norms for the optimal load upon students of particular ages.

\section{CONCLUSION}

Using rational comparison with the norms proposed by Lairda we found the factual condition of students' time load in our primary schools which indicates that the average time load obtained in our measurements is above the optimal limit proposed, therewith ascertaining a state of overload. This state increases the efforts invested the students invest in their work, and is denoted as a negative phenomenon. Overloaded students suffer noxious consequences in their psychophysical, intellectual, moral, emotional and social development. That's why this complex pedagogical phenomenon must be held in the focus and studied further.

\section{ACKNOWLEDGMENTS}

Acknowledgment to the researchers in the scope of a doctor thesis (Phd) titled TIME LOAD UPON STUDENTS IN PRIMARY EDUCATION at the Institute of pedagogy, Faculty of philosophy- Skopje.

\section{Conflict of interests}

The authors declare no conflict of interest. 


\section{REFERENCES}

Alexander, R. J., \& Armstrong, M. (2010). Children, their world, their education: Final report and recommendations of the Cambridge Primary Review. Taylor \& Francis US.

Bezinović, P., \& Ristić Dedić, Z. (2004). Škola iz perspektive učenika: Smjernice za promjene. Institut za društvena istraživanja u Zagrebu-Centar $z a$ istraživanje $i$ razvoj obrazovanja, Zagreb https://www.idi.hr/drzavnamatura/dokumenti/ skola iz perspektive ucenika.pdf

Blank, M. J., Melaville, A., $\&$ Shah, B. P. (2003). Making the Difference: Research and Practice in Community Schools. Coalition for Community Schools, Institute for Educational Leadership, 1001 Connecticut Avenue, NW, Suite 310, Washington, DC 20036.

Hara, S. R., \& Burke, D. J. (1998). Parent involvement: The key to improved student achievement. School Community Journal, 8(2), 9-19.

Lippman, P. C. (2002). Understanding activity settings in relationship to the design of learning environments. CAE Quarterly Newsletter. 